
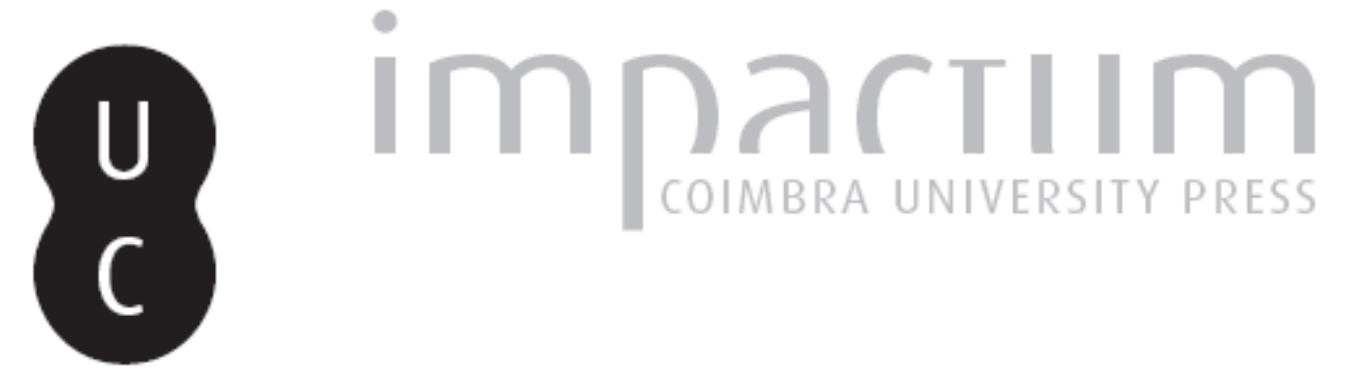

\title{
Crise política e propaganda Ateniense no teatro de Euripides
}

Autor(es): $\quad$ Fialho, Maria do Céu

Publicado por: Centro de História da Universidade de Lisboa

URL persistente:

URl:http://hdl.handle.net/10316.2/23606

DOI:

DOI:http://dx.doi.org/10.14195/0871-9527_21_9

Accessed : $\quad$ 26-Apr-2023 15:21:20

A navegação consulta e descarregamento dos títulos inseridos nas Bibliotecas Digitais UC Digitalis, UC Pombalina e UC Impactum, pressupõem a aceitação plena e sem reservas dos Termos e Condições de Uso destas Bibliotecas Digitais, disponíveis em https://digitalis.uc.pt/pt-pt/termos.

Conforme exposto nos referidos Termos e Condições de Uso, o descarregamento de títulos de acesso restrito requer uma licença válida de autorização devendo o utilizador aceder ao(s) documento(s) a partir de um endereço de IP da instituição detentora da supramencionada licença.

Ao utilizador é apenas permitido o descarregamento para uso pessoal, pelo que o emprego do(s) título(s) descarregado(s) para outro fim, designadamente comercial, carece de autorização do respetivo autor ou editor da obra.

Na medida em que todas as obras da UC Digitalis se encontram protegidas pelo Código do Direito de Autor e Direitos Conexos e demais legislação aplicável, toda a cópia, parcial ou total, deste documento, nos casos em que é legalmente admitida, deverá conter ou fazer-se acompanhar por este aviso.

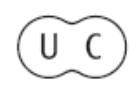



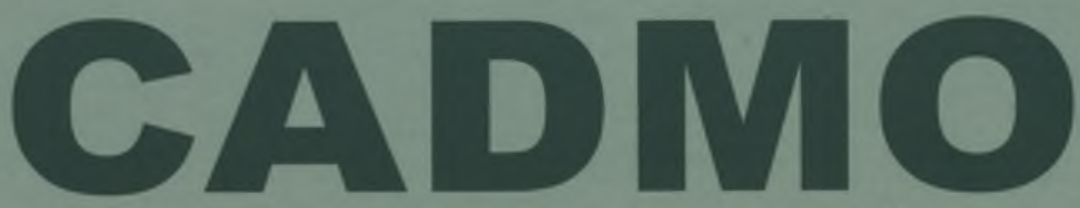

Revista de História Antiga

\author{
Centro de História \\ da Universidade de Lisboa
}

\title{
21
}

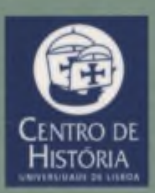

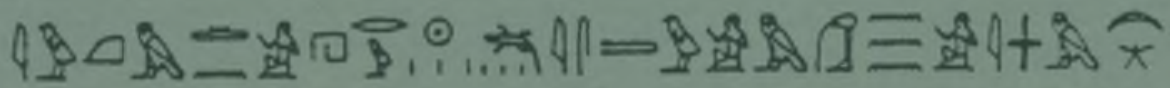

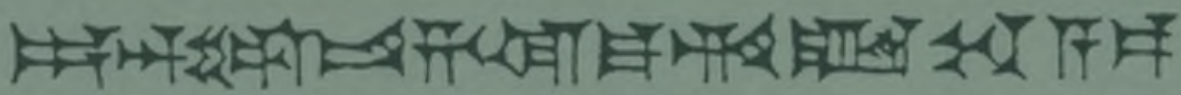

MHNIN AEI $\Delta \mathrm{E} \Theta \mathrm{EA}$ ПH$\Lambda \mathrm{HIA} \triangle \mathrm{E} \Omega$ 


\title{
CRISE POLÍTICA E PROPAGANDA ATENIENSE NO TEATRO DE EURÍPIDES
}

\author{
MARIA DO CÉU FIALHO \\ Universidade de Coimbra/CECH \\ mcfialhofluc@gmail.com
}

\section{Resumo}

O objectivo deste estudo consiste em demonstrar que Eurípides concebeu cada uma das suas "peças atenienses" de acordo com objectivos diferentes, pedidos pela diferença dos contextos históricos da sua conturbada época e das questões políticas mais candentes dessa época que tocavam Atenas. Medeia deve também der incluída no grupo de peças euripidianas de propaganda política.

Palavras-chave: Héracles, Heraclidas, lon, Medeia, Suplicantes.

\section{Abstract}

This paper attempts to demonstrate how Euripides created each one of his "Athenian" tragedies according with different aims, asked by the different historical contexts of his disturbed historical time and the main political questions of that time, concerning Athens. Medea is also to be included in the group of Euripidean plays of political propaganda.

Key words: Heracles, Heraclidae, Ion, Medea, Suppliants.

Ainda que a dimensão política da comédia grega do séc. $V$ a. C. se torne bem evidente, constitui hoje uma consciência adquirida pela investigação na área do teatro grego que essa dimensão política é comum à 
tragédia na pólis, ainda que, de acordo com a natureza do próprio teatro trágico, nem sempre a reflexão e a mensagem política sejam assim tão directas e evidentes ${ }^{1}$.

A suspensão da vida quotidiana dos Atenienses, durante as festividades em honra de Dioniso, para os levar ao acto cultual que representa sentarem-se nas bancadas do Teatro de Dioniso e assistirem aos sucessivos espectáculos dramáticos (tragédia, drama satírico e comédia), ou audição de poemas narrativos, como o ditirambo, representados em competição agónica e sujeitos ao apuramento do melhor, por um júri representativo, só tem sentido se aquilo que é representado diz respeito à polis. No caso específico da tragédia, aquilo que se oferece ao espectador, na acção e nos conflitos e situações extremas a que esta leva as personagens, é, em última análise, uma reflexão sobre a interligação entre o indivíduo, o oikos a que pertence e o macro-sistema da pólis, compreendendo este o universo dos homens, da paisagem e dos deuses tutelares, na sua harmonia conjugada. Essa reflexão, no contexto da tragédia, é proposta sob a forma de uma acção em que afloram e assumem proporções extremas as tensões, as contradições e ameaças entre os vários constituintes da pólis.

Pode, assim, a reflexão que o tragediógrafo propõe ter como referência mais ou menos imediata a vivência e a história próxima da comunidade, ou remeter para grandes questões de fundo, permanentes, aparentemente intemporais porque sempre presentes no horizonte histórico da pólis e nos seus próprios fundamentos. Esta diversidade de perspectivas e modos de construir a narrativa trágica tem, naturalmente, que ver com a própria diversidade de cada autor, com a sua mundividência e com a sua concepção de criar teatro e focalizar a fragilidade e finitude humanas.

É compreensível que tragédia composta em tempos de crise tenda, naturalmente, a condensar na mimesis dramática a problematização de dimensões cruciais dessa mesma crise, de modo a levar o espectador a reflectir e reconhecer, na acção, os agentes catalisadores e o cerne dessa mesma crise que o afecta a si e ao seu mundo, nos nexos quebrados, nos valores infringidos, ignorados, ou na própria imprevisibilidade do que está sujeito ao acaso ou a forças que, residindo no próprio homem, o surpreendem porque nunca este suspeitou que elas o afectassem. Do mesmo modo, quando grandes questões respeitantes à pólis e à vida dos cidadãos estão em debate, é compreensível e espectável que o teatro delas faça eco.

Pode a crise dever-se a agentes internos ou a factores que ultrapassam os limites da pólis e que representam uma ameaça vinda de fora, como seja, para Atenas, o caso das Guerras Medo-Persas ou da Guerra 
do Peloponeso; fatalmente, esta exposição prolongada a uma ameaça vinda de fora, a que não é alheia a política interna, vai degradando o equilíbrio, a economia e o universo de valores em que assenta a própria identidade da comunidade - mais ainda quando se trata de uma guerra da Hélade contra a Hélade. Se tivermos em mente Os Persas de Ésquilo, representados oito anos após a séria ameaça persa que a batalha de Salamina consideravelmente dissipou, torna-se evidente a atmosfera de panegírico patriótico de que não está ausente, todavia, uma mensagem subliminar de chamada de atenção: uma vez desrespeitados ou esquecidos os valores que uniram os Gregos, na luta, o seu destino não andará longe do destino dos vencidos. Até às Euménides, compostas em tempo de "estado de graça" da jovem democracia ateniense, não falta a subliminar advertência de que as deusas guardiãs, propícias, perseguirão os que atentarem contra a harmonia da paz e do sistema.

A crescente hegemonia de Atenas, decorrente da sua posição na Anfictionia de Delos, levou, como é por demais sabido, à progressiva bipolarização da Hélade à volta das duas potências, ateniense e espartana, com o progressivo agravamento de conflitos, em terra-mãe ou no espaço colonizado, que culminará com o deflagrar da Guerra do Peloponeso em 431 a. C. Parte das tragédias conservadas de Sófocles foram compostas durante a guerra e a quase totalidade da obra conservada de Eurípides igualmente o foi. Sófocles optou por uma narrativa dramática determinada pela problematização de grandes questões de fundo da limitação humana no contexto da pólis, como a subversão de valores, a incapacidade de discernir os limites da acção humana e o seu verdadeiro sentido - incapacidade representada como cegueira e sublinhada pelo contraste com a omnisciência divina, através do recurso insistente ao motivo dos oráculos mal compreendidos. O nexo com o contexto histórico próximo não é evidente. O poeta eleva-se acima dele, universalizando a sua perspectiva de tensão, conflito e contradição na existência humana, ainda que o espectador pudesse perceber, na longa e desgastante espera de Electra, na situação de impasse provocada em Filoctetes pela falha de valores éticos determinantes na vida em comum, como a philia, no modo como a argumentação retórica já não persuade e vale menos que o silêncio, em Édipo em Colono, uma sociedade em desagregação dos seus padrões éticos. Curiosamente é esta última peça (406-405 a.C.), numa Atenas desmoralizada, à beira da derrota final na guerra que enaltece, numa das mais belas odes corais, o seu estásimo I, a beleza harmónica da natureza da Ática, onde a presença dos deuses é perceptível e a sua aliança com os homens e a paisagem contribuem para erguer Atenas ao 
estatuto de cidade modelo, imorredoura. Com ela sintoniza um Teseu idealizado, de acordo com o tratamento que foi dado à figura no séc. V, em função de uma política ateniense de afirmação identitária. Pretende o poeta dirigir um apelo à cidade desgastada para que recupere essa Atenas primordial e idealizada, das origens, que contém, na sua piedade e justiça, o segredo da sua imortalidade.

Outro é o caminho da tragédia de Eurípides, tragédia eminentemente de tempos de crise, composta por um homem atento aos grandes debates do seu tempo, por eles tocado, como o atesta a construção das suas personagens em acção, e igualmente atento ao curso de um conflito que ele percebe poder vir a provocar um desgaste fatal em Atenas e na Hélade. Essa consciência parece vir a agudizar-se no decorrer da guerra, como se verá.

Ainda que a cronologia das peças conservadas não possa ser precisada na totalidade, algumas datas nos foram transmitidas e, em relação a algumas das peças não datadas, é possível estabelecer, com uma razoável margem de probabilidade, uma cronologia relativa. Da primeira metade da Guerra do Peloponeso parecem datar a maior parte daquelas a que podemos chamar as peças de propaganda ateniense. Delas se distancia, cronologicamente, com forte probabilidade, o lon2.

A propaganda, que pressupõe em Eurípides um discurso assumido ou subliminar de panegírico, pode assentar numa estratégia de reconhecimento de uma harmonia genuinamente helénica que encontra na pólis ateniense a sua sede verdadeira e única - o que supõe que essa harmonia se perdeu no resto da Hélade, ou em partes específicas da Hélade - ou na acção e carácter de figuras de governantes emblemáticos que representam, como que por um processo de sinédoque, os valores genuínos de Atenas. E esses são os valores que não só deveriam ser os de Atenas, mas de toda a Hélade. Assim, Egeu, Teseu, Demofonte contrastam com os tiranos de espaços desarmónicos.

Importa, neste contexto, reflectir sobre a construção de Medeia. A peça foi composta para a sua representação nas Grandes Dionísias da Primavera de 431 a. C., ano em que deflagram as hostilidades abertas da Guerra, após o conflito naval entre Atenas e Corinto. Eurípides recorre ao antiquíssimo mito dos Argonautas, de que já a Odisseia dá conta (12.69-70) e que Píndaro canta ( $P$. 4. 71-251), e situa o par Medeia-Jasão, após a fuga da corte de Pélias, na sequência da morte deste, precisamente em Corinto, onde a acção decorre. A traição e abandono, por parte de Jasão, de que Medeia vai tomando conhecimento, geram nela a ira revoltada da estrangeira de paixão e sentimentos desmedidos, que seguiu Jasão até à 
Hélade, abandonando a sua terra natal, recorrendo à violência e ao poder da magia por amor ao Grego com quem havia selado compromissos de amor. O motivo do Bárbaro fiel a valores éticos da Hélade civilizada que o Grego, todavia, infringe, apesar de os evocar - motivo tão do agrado de Eurípides e que o dramaturgo futuramente desenvolverá, em peças de temática de guerra -, está já presente nesta peça. Philia e philos são conceitos recorrentes na boca da protagonista, no contexto do reconhecimento do pacto outrora selado, quando Medeia ofereceu o seu auxílio para que Jasão consiga alcançar o Velo de $\mathrm{Ouro}^{3}$. $\mathrm{O}$ apertar das mãos direitas de ambos foi tomado pela princesa bárbara como sinal inquebrantável de laços de reciprocidade que passaram a uni-los, de acordo com os padrões éticos da philia grega. Assim Medeia seguiu Jasão até à Hélade, confiada na paixão e compromisso que pensava uni-los na fundação do seu oikos, no leito em que a sua união se celebrava, lugar da geração dos filhos. Tais pactos apresentam-se, na peça, quebrados por Jasão em função da sua sede de prestígio e poder, alcançados através das núpcias com a filha do rei de Corinto, Creonte. Se o cinismo de Jasão é patente no confronto entre o Argonauta e Medeia, nos falsos motivos que aquele evoca para legitimar o seu comportamento (vv. 523-575), a frieza implacável do rei de Corinto em relação à estrangeira abandonada, sem protecção, com os seus filhos, é chocante. Jasão acena com a protecção que tenciona dar aos filhos. Creonte, em contrapartida, é claro: expulsa a mãe sem pátria e os seus filhos, de imediato, da terra de Corinto - ainda que venha a cometer o erro fatal de conceder a Medeia mais um dia, o dia de que ela necessitará para executar a sua sangrenta vingança.

Esta tragédia, pela sua força dramática e riqueza de dimensões que envolve, presta-se a múltiplas leituras e abordagens, desde a perspectiva de compreensão da tensão entre sentimentos, dignidade e razão que determina a acção da protagonista, à leitura do binómio Grego-Bárbaro posto em causa ${ }^{4}$. Tais leituras complementam-se, sem dúvida. Mas é possível, como já tem ocorrido, que nelas se sinta o papel dramático de Egeu, surgido como que por acaso, vindo de outro contexto mitológico, com preocupações que parecem constituir factor dispersivo, como um papel algo forçado ${ }^{5}$. E é esta a questão fulcral que justifica a referência a Medeia no contexto de uma reflexão sobre a propaganda ateniense no teatro de Eurípides. Como se viu, não é arbitrária a escolha do espaço de Corinto como o cenário trágico para a peça representada em 431 a. C. O Coro de Mulheres Coríntias sofre com Medeia a sua sorte, está próximo daquela de cuja casa se confessa amigo e apenas se distancia, horrorizado, perante a dimensão da vingança da maga traída. O Coro representa, sem 
dúvida, a cidade, distanciada da intriga palaciana dos seus governantes, promotores da proposta a Jasão que leva à desarticulação do seu oikos e à quebra dos seus compromissos e responsabilidades criadas. Creonte representa o governante frio, sem escrúpulos nem valores, centrado apenas nos seus interesses e nos de sua casa. Com esta construção da figura prepara Eurípides o contraste com o mítico rei de Atenas, que faz vir à cena para o exibir agindo em oposição absoluta a tal tipo de comportamento. Medeia expõe o seu infortúnio perante Egeu e é este o único homem grego a reagir, apodando Jasão de infame (kakos, 699) e de "vergonhosa em extremo" a sua actuação (ergon aischiston, 695). Em oposição a Creonte, Egeu atende o pedido de acolhimento de Medeia, formulado de acordo com as formalidades que o convertem num acto de súplica. Ainda que Egeu seja sensível à promessa de Medeia de lhe abrir o caminho para a fertilidade, Egeu preocupa-se em sublinhar que, antes de mais, é por respeito aos deuses que a acolhe, e só depois se refere ao seu desejo de alcançar descendência, que será satisfeito (719-721).

Não deixa de ser expressivo o contraste entre Jasão, integrado já no contexto do poder de Corinto, que abandonando os filhos e destruindo a casa que fundou com Medeia, ou Creonte, que desrespeita a união e os filhos de Jasão, e Egeu, que reconhece ser o desejo de descendência uma vocação natural do homem.

O espectador não se encontra, propriamente, perante um retrato idealizado do governante que representa Atenas, mas o seu retrato é já parcialmente emblemático e o contraste com os representantes do poder de Corinto é flagrante; ora essa técnica de contraste de figuras representativas é reconhecidamente euripidiana. O Coro, no estásimo III, após a cena de Egeu, enaltece a geração dos Erectidas, abençoados por pertencerem a esse espaço sagrado e harmonioso que é o da Ática, em que os deuses habitam e a natureza é suave e perfumada. O contexto do canto antecipa, assim, o do estásimo I do Coloneus, o mais belo elogio de Atenas, entoado após Teseu ter acolhido Édipo em solo ateniense. Medeia, para além de todo o potencial hermenêutico que contém, representa, assim, a mais antiga das peças euripidianas em que o panegírico de Atenas como espaço de harmonia e espelho de valores gregos está presente. Tendo em conta o horizonte histórico da sua representação, o contraste Creonte/Egeu confere a esse panegírico uma natureza publicitária.

Existem similaridades na integração, na estrutura dramática, da figura de Egeu, em Medeia, e na de Teseu em Héracles. Em ambas as peças os soberanos de Atenas chegam espontaneamente: na primeira Egeu 
e Medeia encontram-se pela coincidência de o percurso de Egeu, ao ir consultar o oráculo sobre a sua infertilidade, o ter levado a Corinto. Só por esse motivo, e pelo facto de aí ter chegado quando chegou, Medeia nele encontra o Ateniense a quem se dirige como suplicante. Não estamos perante uma típica peça de súplica, como o são Os Heraclidas e As Suplicantes. No entanto, a súplica e a resposta de acolhimento de Egeu criam a oposição com o tirano de Corinto. É, sobretudo, dessa oposição que ressalta a diferença de atitude de Egeu/Atenas no respeito a valores e princípios ético-religiosos helénicos.

No seu Héracles Eurípides confronta o espectador com uma versão do mito diversa daquela que Sófocles utilizou em As Traquínias e que a cerâmica grega também atesta ${ }^{6}$ : a do fim dos seus trabalhos, coincidente com o fim da sua existência ao regressar a Tráquis. Héracles agonizante, por acção do veneno da sua túnica, pede que o ponham sobre a pira armada no cimo do Eta. Daí o arrebata Atena para o Olimpo. No Héracles euripidiano o herói regressa dos seus trabalhos até Tebas - outro dos espaços tradicionalmente disfuncionais no contexto da narrativa trágica - onde o seu pai humano, Anfitrião, sua esposa Mégara, filha do assassinado rei de Tebas, e seus filhos o aguardam, inseguros e ameaçados pelo tirano Licos, invasor de Tebas e regicida, ocupante ilícito do trono de Creonte. Já idoso, Anfitrião tenta, angustiado, assegurar o papel do kyrios da casa de Héracles, protegendo-a, quando a sua idade o coloca já na situação de carecer dos cuidados da geroboskia. A peça abre, significativamente, com este frágil grupo concentrado aos pés do altar de Zeus, frente à morada de Héracles. A lógica da tirania leva a que Licos planeie matar a prole de Héracles, assim como Mégara e Anfitrião (vv. 37-43), para impedir a possibilidade de uma vingança futura. De facto, o tirano invasor de Tebas mostra-se, em toda a sua crueldade, no episódio I, ameaçando inclusivamente os Anciãos do Coro, antigos companheiros de armas de Anfitrião, pela sua solidariedade para com o grupo desprotegido (vv. 247-251).

A solidariedade - ou a falta dela - constitui o objecto das reflexões amargas de Anfitrião, frente a Licos: perante a coragem e os serviços de Héracles, prestados a Tebas e à Hélade, expurgando-a de monstros, onde está a capacidade de respeitar os princípios de reciprocidade que a ética grega naturalmente impõe? Não é apenas Tebas, mas toda a Hélade, que o ancião interpela com a sua crítica (vv. 220-229): à casa de Héracles resta apenas o apoio de um "amigo sem forças" (asthene philon, 228).

Quando a esperança parece voltar a brilhar com o regresso do herói, na posse do seu vigor e dignidade, de novo se abate um terrível destino 
sobre a sua casa, por acção de deuses a que Eurípides deu um contorno homérico. O eterno ciúme de Hera converterá Héracles enlouquecido no próprio destruidor de sua casa, no assassino de seus filhos e de Mégara. Para o herói, agora maldito pelo derramamento de sangue da sua própria progénie, perde o sentido encarar a luz do dia e manter-se no mundo dos vivos (vv. 1146-1152). Se vivesse, o seu destino seria, fatalmente, o exílio - um duplo exílio, já que ele é também exilado de Argos. Que cidade pode, ainda, acolher o autor de tais actos? A mesma pergunta se põe em relação a Medeia ( e o Coro de Coríntias formula-a, na segunda parte da ode de encómio a Atenas).

A contrariar a amarga expectativa de Anfitrião, Teseu surge, vindo da fronteira entre a Ática e a Beócia, para acorrer em auxílio do amigo em desgraça, em nome de antigos favores que de Héracles recebeu, quando este o salvou do Hades (vv.1169-1171). Héracles saúda-o como syngenes, philos, philtatoi xenon emon (vv. 1154, 1156). Em foco está, a partir do momento em que Teseu entra na cena, vindo sem que alguém tivesse pedido o seu auxílio, mas de motu proprio, espontaneamente, o motivo da philia, verbalizado com insistência ${ }^{7}$. As rheseis proferidas por Teseu apresentam um tom algo formal e retórico, explicável pelo facto de a figura do mítico rei de Atenas ter sido submetida a um processo de idealização, incorporando os valores ideais da Cidade, como fruto de um programa político que o próprio contexto dos acontecimentos exigiu e da necessidade de Atenas carecer de um espelho de virtudes onde reforçasse a sua consciência identitária ${ }^{8}$ - de cuja elaboração está longe o Egeu de Medeia.

Teseu chega para conduzir Héracles, como seu hóspede, para Atenas. Aí terá o herói poluído o abrigo e acolhimento no exílio que, necessariamente, se impõe após a cadeia de homicídios, ainda que involuntária. Também Medeia fora acolhida por Atenas, após a morte de seus filhos.

À amarga crítica sobre a total ausência de gratidão e reciprocidade amiga, em toda a Hélade, feita por Anfitrião, surge, assim, uma nobilíssima excepção com Atenas, representada por Teseu. Tal excepção é sublinhada pela técnica do contraste entre Teseu e Licos, como o fora, em Medeia, pelo contraste entre Egeu e Creonte. Ganha força a linguagem cénica, no quadro dos dois amigos, Teseu apoiando Héracles, que se encaminham para Atenas, consoante Héracles diz, como um zeugos... philion (vv.1401-1404) .

Que força é a desta cidade, capaz de, em obediência a imperativos éticos, absorver o que é desmedido e maldito e diluí-lo, fortalecendo-se a si mesma e à sua imagem? Essa misteriosa energia perpassa por 
Euménides e estará presente em Édipo em Colono - é a força capaz de suportar e alimentar a própria natureza dos heróis e do seu culto. Só a cidade ideal e justa a possui, de modo a absorver e integrar em si tais excepcionalidades sem perder a sua harmonia e equilíbrio, mas reforçá-los.

Não existe uma datação certa para Héracles. Parmentier ${ }^{10}$, na sua introdução à edição e tradução da peça situa-a em 424, quer pela coincidência de formulação entre o v. 183 desta tragédia e o v. 1048 de As Nuvens, de Aristófanes, o que me parece um frágil argumento, quer pela proximidade temporal com a fundação de uma nova cidade junto a Tráquis, por parte dos Lacedemónios, a que estes deram o nome de Heracleia, como que para legitimar a sua ligação à figura de Héracles e, assim, à reivindicação da região do Eta. Outros estudiosos, apoiados em critérios de ordem métrica, preferem uma maior proximidade com As Troianas, de 415 a.C., ainda que admitam a possível datação entre 420-416 a. $\mathrm{C}^{11}$. Lesky, ao tender para a proximidade com As Troianas, nega-se a ver Héracles como uma das peças «atenienses". Defende Lesky que é outra a questão central da peça - a típica interrogação euripidiana, à luz de Xenófanes, sobre os deuses e, por outro lado, a humanização das motivações da acção e do sofrimento ${ }^{12}$.

Permito-me discordar do ilustre helenista. É de todo pertinente a sua fina observação sobre as alterações introduzidas na tradição dos trabalhos de Héracles por Eurípides: eles não foram impostos, mas voluntariamente assumidos para obter perdão para seu pai e tentar possibilitar a este o regresso a Argos; no entanto, a complexidade e o carácter multifacetado da dramaturgia euripidiana admite que esta peça, além do mais, esteja também incluída no conjunto das peças patrióticas. Inclinar-me-ia para data mais próxima de 420 a. C. Resultaria, daí, uma proximidade global das tragédias à volta de Héracles, incluindo As Traquínias sofoclianas, e das restantes peças "atenienses" de Eurípides, incluindo as peças perdidas Erecteu, provavelmente de 422 a. C., e Teseu, anterior a esta. Está ainda bem viva, na memória dos Atenienses, a fundação de Heracleia. Por outro lado, a figura de Licos como invasor atinge o coração do público, após invasões sucessivas, com devastação da Ática. Héracles é levado para Atenas pelo gesto de philia de um Teseu idealizado. Assim associa Eurípides, no seu tratamento criador do mito, o herói nacional de uma Hélade que o não merece (como se deduz do lamento de Anfitrião) à pátria ateniense que acaba de se tornar merecedora dele, pela mão do seu governante.

Os Heraclidas e As Suplicantes constituem genuínas tragédias de súplica ${ }^{13}$, ambas apresentadas em trilogias anteriores à que incluía a 
representação de Héracles. Um conjunto de suplicantes pede protecção ou solicita daquele a quem se dirige como suplicante a tomada de uma iniciativa que, em si, trará uma ameaça de segurança à comunidade ou a empurrará para a guerra. Todavia, aquele que atende a prece colherá um inesperado benefício para a sua comunidade - neste caso, Atenas, recompensada pela prova de carácter e de piedade a que o seu governante foi submetido.

Em ambas Eurípides mantém o recurso à técnica do contraste de comportamento entre o chefe político ateniense, idealizado, e o antagonista que persegue o grupo em súplica ou the provoca sofrimento, por um comportamento desumano e ímpio. Em Os Heraclidas é Demofonte, um dos dois governantes de Atenas, filhos do mítico Teseu, que contrasta com Euristeu, o implacável soberano argivo, cujo braço perseguidor é representado pelo seu arauto Copreu. Em As Suplicantes Teseu opõese, simultaneamente, a Adrasto e a Creonte (v.358). Ao representar Atenas, de cuja democracia Eurípides o apresenta, anacronicamente, como fundador, opõe-se a Tebas. Os Tebanos e os poderosos de Tebas permanecem como a referência do comportamento hibrístico e distorcido, que não obedece a leis invioláveis, como seja a do direito à sepultura dos mortos - só no v. 358 o tirano de Tebas recebe nome: Creonte. A distorção comportamental parece alastrar à cidade e aos senhores da guerra, ainda que o motivo da recusa de sepultura leve o espectador a ter em mente Creonte, por via da memória deixada pela representação da Antígona sofocliana.

É voz quase consensual que Os Heraclidas teriam sido compostos entre 430 e 427 a. C. ${ }^{14}$, numa época em que as forças lacedemónias haviam já invadido a Ática, mas poupado a Tetrápole, segundo Diodoro Sículo, por respeito para com o acolhimento dos Heraclidas ${ }^{15}-0$ que não ocorre com a ruinosa devastação do Verão de 427. A razão pode, porém, ser outra: os Espartanos evitaram Atenas e o coração da Ática em tempo da primeira epidemia aguda de peste.

Após esta data perderiam sentido as palavras finais de Eristeu, prometendo imunidade ao solo ático.

Escorraçados desde Micenas e Argos, os indefesos descendentes de Héracles, perseguidos por toda a Hélade pela raiva de Eristeu, acolhemse, como suplicantes de Zeus, junto do altar e no interior do templo do deus, em Maratona. Dois anciãos, Alcmena, mãe de Héracles, e lolau, antigo companheiro de armas do herói levado para o Olimpo, zelam pelos jovens - Alcmena pelo grupo feminino, no templo, e lolau pelos rapazinhos, junto ao altar. A consciência da sua impotência é angustiante 
para o velho: em nome dos antigos laços de amizade está determinado a ir além das suas forças, numa fase da vida em que já chegou o momento de ser cuidado e não de ter jovens a seu cargo.

As circunstâncias se encarregam de demonstrar que é fundamentada a angústia de lolau - já no prólogo ocorre uma dupla violência, praticada por alguém cuja função está sob a tutela de Zeus. $O$ arauto de Euristeu, que chega, da parte do seu senhor, não respeita nem o estatuto de suplicantes de Zeus dos elementos do grupo que tem perante si, nem a velhice de Iolau, cuja resistência prontamente derruba. $\mathrm{O}$ arauto está seguro de que Atenas não se envolverá numa guerra contra o soberano do espaço de Micenas/Argos, isto é, lacedemónio, por um punhado de seres frágeis. $O$ filho de Teseu far-lhe-á perceber que outra é a realidade (vv.237-252). Entretanto, entre a rhesis do arauto Copreu e a de Demofonte, Iolau apela para a protecção ateniense, invectivando quem perseguiu suplicantes pelo espaço da Hélade - que não ofereceu resistência à violência argiva - e precisando que espaço foi esse: o de cidades da Acaia, o de Tráquis, cidade em cuja proximidade e por cujo desejo os Espartanos se preparavam para fundar a colónia de Heracleia, em 426 a. C.

lolau opõe, assim, num discurso agónico perante um interlocutor, mas de captatio perante outro (Demofonte), as altas expectativas postas por si sobre Atenas, como bastião dos genuínos valores da Hélade, e o juizo formulado sobre as póleis de espaço potencialmente adverso. Está, assim, aberto o caminho para a rhesis que definirá o retrato de Demofonte e os padrões por que este se rege: respeito religioso, leis de reciprocidade de philia e de laços de parentesco, responsabilidade do governante que não pode tolerar a invasão do território da Ática e o sacrilégio prestes a ser cometido. O agon entre Copreu e Demofonte traz à discussão o motivo da guerra justa - a cidade justa deve evitar a guerra, mas não hesita perante a defesa daqueles que tem sob a sua tutela (no palco, o grupo de suplicantes, no contexto real, póleis que estejam sob a sua protecção). Tal gesto de estratégia inspira-se na consciência de que esse é um dever religioso, de acordo com a ordem e os preceitos divinos que dão sentido a uma ética política. A causa justa, percebe-se nas palavras do governante de Atenas, confere força à cidade e ao seu empreendimento - tornam-na imune à previsível contra-ofensiva de Argos. Pode objectar-se, em relação à idealização do governante e do sistema político da cidade governada que Demofonte não parece escutar Atenas para tomar a decisão da guerra. Trata-se, creio, de um processo de síntese dramática pelo qual Demofonte representa e incarna, por sinédoque, a cidade que governa e cuja disposição exprime. Os princípios que presidem 
à sua decisão correspondem a padrões de ética político-religiosa que não variam dentro da cidade e não deveriam variar na Hélade.

Que representa, então, Argos nesta tragédia? Haverá uma relação propositada e modelada por Eurípides entre a Argos mítica e a Argos histórica do momento? Embora se tenha de ter sempre em conta que a cronologia da peça não é segura, penso que tal relação entre as duas "Argos» existe e é propositadamente apresentada por Eurípides como ela a apresenta. Como acima ficou sublinhado, o espectador confronta-se com um espaço de consonância ético-política, que é o espaço governado pelo bom político - Demofonte - e um espaço de dissonância e distopia, coincidente com o eixo Micenas/Argos e também Esparta (vv.741-742) Este espaço vale como Esparta e a aliança dos Peloponésios, contra a Liga Ático-Délica.

A inimizade subliminar de Argos em relação a Esparta é silenciada pelo perigo da proximidade desta. Por isso mesmo, a história de Argos e das suas tomadas de posição, ao lado de Esparta ou de Atenas, é sinuosa e ambígua. Nos anos 20 Argos estava ainda vinculada a um tratado de trinta anos de paz com Esparta, celebrado em 451 a. C. - assim, cessaria o tratado em 421 a. C. Esparta temia esse termo. E Atenas? Atenas estaria, certamente, expectante em relação a futuras posições de Argos.

Constitui uma técnica corrente na dialéctica de cariz político o recurso à argumentação que exagera as posições do antagonista hesitante e o retrata como alguém radicalizado nessas posições. Tem tal técnica o objectivo de provocar a reacção contrária, de levar o interlocutor a desvincular-se das posições que lhe são atribuídas. Não tendo sido Argos, neste período de guerra, antagonista frontal de Atenas, não estaria Eurípides, em Os Heraclidas, a recorrer à estratégia acima descrita, na sua representação de Argos no espaço de representação ateniense, com o pensamento já posto em 421, ano em que o tratado Argos-Esparta cessaria, a fim de forçar Argos a posicionar-se, nesse futuro não longínquo, fora da esfera de influência espartana? Os acontecimentos demonstrarão essa atitude de Argos após o fim do tratado. A Élide, Mantineia, Argos, Corinto e os Calcídios saem da Liga Peloponésia e formam uma liga independente, pró-ateniense. A luta pela preponderância no Peloponeso culminará em 418 a. C., com a batalha de Mantineia e a derrota dos Argivos, apesar do auxílio militar ateniense.

Uma vez vencido o exército argivo sob o comando de Euristeu, este é capturado. O espectador terá, diante dos seus olhos, o antagonista vencido pelo braço retemperado de lolau, apoiado pelas forças atenienses. Em futuras produções trágicas Eurípides explorará este tipo de 
situação dramática, expondo, aos olhos dos Gregos, os Troianos vencidos e submetidos à força helénica - e encenará, desse modo, as cruéis contradições da guerra e as próprias contradições, a partir daí iluminadas, da identidade grega, pautada por comportamentos não-gregos. Já aqui as encontramos, focalizadas a partir de uma perspectiva muito própria e diversificada: perante a iminente chegada do seu inimigo vencido, Alcmena - que não é ateniense, mas micénica de origem - dá expressão ao seu ódio imenso contra o vencido, saboreando antecipadamente a vingança e a morte deste (vv. 869-882). A mãe de Héracles não perdoa a lolau ter poupado a vida ao inimigo de sempre, mas. O código ético da guerra assim o impõe: aos prisioneiros capturados vivos deve a vida ser poupada. A derrota é, por si, humilhação bastante. O estásimo que o Coro de Anciãos de Maratona entoa, de seguida, é composto por dois pares de estrofe-antístrofe que correspondem a quatro momentos temáticos: o enaltecimento da harmonia da dança e da música, na paz do festim, equivalente aos dons graciosos de Afrodite e à compensação que significa a boa fortuna dos amigos (eutychia, v.896), num contexto existencial dominado pela mudança; o elogio da Cidade justa e exortação à sua perseverança na justiça, perante os sinais de manifestação da protecção divina; a exaltação do destino de Héracles, elevado ao Olimpo para as núpcias com Hebe (o Coro repudia a versão da morte na pira, no alto do monte Eta, o que, no contexto, contém alusões políticas em relação a Heracleia, cuja fundação os Espartanos preparam); o motivo «Héracles" dá azo a recordar a protecção de Atena, cuja cidade e cujo povo salva agora a descendência do herói perante a hybris de um homem violento. Este último tema cria ao Coro o ensejo de formular o voto de moderação e afastamento de paixões violentas do seu espírito (vv. 926-927). Este voto representa, num contexto de elogio de Atenas como a cidade sophron, e no contexto de ligação do mito do herói nacional da Hélade à Cidade, uma advertência a Alcmena, possuída pela violência de paixões que a levam a ignorar princípios éticos militares, no contexto de uma guerra justa, movida por Atenas em defesa dos Heraclidas.

Demofonte já não estará presente no êxodo, apenas Alcmena, o Coro de Anciãos e Euristeu, acorrentado por um grupo de servos, dos quais um falará, em nome da ética ateniense. A antiga rainha de Tebas não se mostra à altura da dignidade do Servo, voz dos valores éticos helénicos ${ }^{16}$. Em peças posteriores veremos também este motivo convertido em topos do gosto euripidiano: são os mais humildes quem, frente a personagens de linhagem, se revelam mais nobres de carácter. Esta cena de Os Heraclidas apresenta a peculiaridade de a voz da sensatez 
e da justiça, posta na boca do Servo, representar a voz de Atenas. É o próprio prisioneiro Euristeu quem surpreende o público: ele é, agora, capaz de uma reflexão sobre o seu próprio comportamento e capaz de reconhecer Atenas como uma cidade sophronousa (v. 1012), que sabe colocar acima da inimizade dos mortais os preceitos de natureza divina. O ódio de Alcmena, que prevalece sobre a resistência do Coro e do Servo, sacrifica Euristeu e, com isso, atrai sobre si ( e sobre o espaço de origem que ela representa) a poluição sacrílega (v. 1011). Grato perante a nobreza de Atenas, Euristeu dá memória e força ao antigo oráculo de Apolo: tal como o Édipo do mito de Colono, Euristeu, do seu túmulo de estrangeiro em terra da Ática, nas proximidades de um templo de Atena, em Palene ${ }^{17}$, irá converter a sua gratidão para quem o poupou em força benéfica. Essa força protegerá Atenas dos invasores e irá converter-se no pior inimigo dos descendentes dos Heraclidas, como resposta à crueldade de Alcmena.

O final da peça apresenta lacunas e traços de conservação duvidosa. No entanto, não é de rejeitar que seja genuína a reacção final de Alcmena, acicatada pelo ódio desmedido, ao ordenar a morte de Euristeu e o abandono do seu cadáver aos cães (v. 1050). Trata-se de um topos de vingança em excesso, a que Sófocles recorre para a acção de Antigona e que sugere na boca de Electra (El. v. 1477-1478), na peça homónima, em relação a Egisto. As palavras finais do Coro não têm de ser de concordância, nem podem ser de concordância com esta crueldade sacrílega, se se tiver em conta que entre a fala final de Alcmena e a fala final do Coro existe uma lacuna ${ }^{18}$. A entrega do cadáver a "amigos que o venham procurar " (v. 1023) pode ser pura ironia de Alcmena.

Atenas cumpriu o seu dever e receberá, por parte de quem menos seria de esperar, a recompensa por tê-lo feito - recompensa sancionada pelos deuses. Todavia, o dramaturgo chama a atenção para o facto de a correcção ético-política não ter sempre como compensação a reciprocidade. Esta realidade facilmente se aprende na guerra. Atenas deve elevar-se, contudo, acima dessa expectativa e agir em conformidade com o que é justo e sensato à luz de leis que transcendem os homens - ainda que o que é justo e sensato a possa envolver numa guerra que, e só nessas condições, será justa.

Sanciona Eurípides as posições de Atenas ao tempo? Ao apresentar Atenas, através do seu governante, como a cidade justa, piedosa e sensata, aberta, num gesto de generosa compaixão, ao acolhimento dos filhos de Héracles, Eurípides inicia o tratamento da aproximação mitológica de Atenas ao herói nacional da Hélade - o que culminará em 
Héracles. Atenas eleva-se, pelo menos, acima da Liga antagonista, como verdadeiro espírito da Hélade. O deprimente final da peça sugere apenas que não deve a pólis ateniense alimentar expectativas de ver todo o gesto correcto reconhecido e recompensado, mesmo que, na sua correcção ético-política, corra perigos em nome de quem a vier a trair. A lógica dos acontecimentos leva, no entanto, a que a recompensa surja, sancionada pelo divino, de onde menos se espera. Também na vida política a Tyche exerce a sua acção. Com esta perspectiva convida o dramaturgo a que a Atenas do seu tempo e da Realpolitik se eleve por acção de uma consciência do que é a sua identidade ideal, identidade essa que deve ter como objectivo ético-político da sua conduta colectiva ${ }^{19}$.

Em As Suplicantes Eurípides recorre ao modelo de uma cena de abertura de súplica, com variação dos elementos componentes e da topografia do sagrado. A acção passa-se frente ao templo de Deméter, em Elêusis. O grupo de suplicantes é constituído, como em Os Heraclidas, por personagens caracterizadas pela sua fragilidade - fragilidade, desta vez, no género feminino. Trata-se de um conjunto de mulheres idosas, que constitui o Coro, e que encontram na idosa Etra uma mulher que compreende a sua dor e faz sua a causa daquele grupo. $O$ dramaturgo associa, através de um primeiro elo feminino, o ciclo mitológico tebano a Atenas e a Teseu, convertendo Elêusis no ponto de intersecção entre Argos, Tebas e Atenas. O grupo de suplicantes não vem pedir auxílio perante uma perseguição de que seja alvo, mas traz consigo um doloroso pedido: que Atenas, por intermédio de Teseu, intervenha para recuperar os corpos de seus filhos, os generais mortos no ataque às portas de Tebas, e que os senhores de Tebas se recusam a entregar.

Eurípides põe em cena Etra, em Atenas, como a venerável mãe de um Teseu idealizado, que incarna, de modo mais nítido que Demofonte, os valores ideais da Helenidade, respeitados e incontestados na polis que governa. Ele aparece, anacronicamente, como o fundador da democracia, aquele que dotou Atenas de liberdade e direito ao voto para todos (eleutherosas tend'isopsephon polin, v. 353). É em função dessa idealização que o destino de Etra foi alterado na narrativa do mito - da sua permanência em Tróia não se fala, pois evocaria aspectos menos nobilitantes das aventuras de Teseu. Assim, Teseu vem à cena movido por um cuidado filial modelar (v. 89-91) que o torna sensível ao quadro do desespero de outras mães idosas ${ }^{20}$.

O motivo da hybris do governante de Tebas que recusa entregar os cadáveres para que suas mães lhe prestem honras fúnebres representa, com toda a probablidade, um eco da acção de Antígona. A figura de Creonte 
ficou, no espírito dos espectadores atenienses, associada a essa infracção a leis sagradas, naturais e universais, que, na peça, são identificadas como leis de todos os Gregos, sinónimo de civilização e de identidade cultural. Etra alude às nomima... pases... Hellados (v. 311) e Teseu, pela boca do seu arauto, anuncia que a sua acção militar em Tebas tem como objectivo "Salvaguardar a lei de todos os Gregos" (ton Panellenon nomon, v.671). Todavia, este anúncio representa a solução extrema, uma vez esgotadas as propostas de conciliação e acordo pacífico (vv. 346 sqq.) - solução extrema que, por sua vez, converte Teseu no herói pan-helénico ${ }^{21}$.

Tebas, como espaço distópico, força Teseu a tal empreendimento militar, bem sucedido, já que, tal como as suplicantes, ele assume a causa justa, está dentro da justiça e do direito, ao combater, em resposta aos deveres perante quem suplica e em nome da ética grega.

O motivo da guerra justa e justificada, por parte de Atenas, aflora de novo, nesta peça ${ }^{22}$. Teseu representa Atenas, elogiada pelo Coro no estásimo II como a pólis cujo governante é espelho dos seus valores ${ }^{23}$. Etra (vv. 324 sqq.) critica duramente a paz podre das outras póleis gregas, refugiadas numa neutralidade cobarde e sem glória, incapazes de se baterem pela justiça. É a cidade livre (eleuthera polis, v. 405) que Teseu enaltece frente ao arauto tebano. Este procura o tirano de Atenas para lhe transmitir a mensagem de que é portador, projectando sobre a cidade um regime que lhe não é próprio (em Tebas o poder é de um só homem, vv. 409-410). A rhesis proferida por Teseu em vv. 426-462, neste agon sobre concepções de estado, condensa o programa político da Atenas idealizada - ausência do pior dos males, a tirania que gera a arbitrariedade, vigência da isonomia, assente numa constituição (leis escritas, v. 433), que permite a liberdade e a parrésia, próprias de uma cidade onde o povo governa.

No Arauto se configura o retrato de uma realidade política oposta, feita de violência e ameaça de agressão que veicula. Todavia, nas palavras do Arauto transparece a nostalgia da paz e da concórdia (vv. 486 sqq.) a que todo o homem aspira - a Paz, tão querida às Musas.

Adrasto acompanha as suplicantes e reforça o seu pedido. No entanto, Teseu censura o senhor de Argos, que se deixou arrastar para a guerra por Polinices e aceitou aliar pelo casamento à sua casa dois estrangeiros - Polinices e Tideu. Não é a força do pedido de Adrasto mas a retórica do sofrimento das mulheres e a do afecto e respeito para com Etra que o persuadem. Na sua tentativa de persuasão, Adrasto tem de justificar como, apesar da sua proximidade a Esparta, recorre a Atenas: Esparta é insidiosa e insensível (vv.187-188). 
Teseu levará a cabo a sua empresa e resgatará os cadáveres dos generais mortos. A sua sepultura exigirá, por intervenção final de Atena ex machina, um juramento celebrado entre Adrasto e Teseu - os Argivos não pegarão em armas contra Atenas, sob pena de atraírem sobre si a ira dos deuses. O sacrifício que acompanha o juramento, ao ser feito sobre o tripé de Delfos, a cuja cerimónia votiva Teseu e Héracles parecem ter andado associados, alia, mais uma vez, o herói pan-helénico por excelência ao mítico representante das virtudes atenienses e alia os espaços sagrados de Elêusis ao espaço sagrado pan-helénico de Delfos, por intervenção de Atena.

Esta é, das peças conservadas de Eurípides, aquela que concentra uma propaganda política mais densa e mais complexa, quer na representação da cidade, através do seu governante, como universo político idealizado e paradigmático para toda a Hélade, quer nas mensagens decorrentes do estabelecimento de contrastes com espaços distópicos. Desprende-se da peça uma nostalgia de paz desejada, ainda que no contexto da guerra justa - uma paz com nobreza e brilho, não a da neutralidade pusilânime de póleis que se fecham em si, num contexto de conflito generalizado. A Argos, que não encontra apoio em Esparta, é dirigida a censura por uma política de alianças que a arrastaram à desgraça e é imposto, pelos deuses, o compromisso de não-agressão a Atenas, para de futuro. Só assim Argos reencontrará a sua estabilidade.

Não é conhecida a data de representação da peça. Todavia, o drama dos cadáveres por sepultar e o sofrimento dos seus familiares, que lhes querem prestar honras fúnebres, ainda que tenha antecedentes temáticos na tragédia grega (Ájax, Antígona), parece espelhar a experiência traumática dos acontecimentos em Esfactéria, em 424 a. C., possível terminus a quo para esta tragédia ${ }^{24}$. Os acontecimentos dos anos subsequentes deixam perceber, simultaneamente, a tensão geral vivida na Hélade e o desejo de paz. Em 424-423 Atenas renova o tratado da paz de Cálias, com os Persas e em 423 celebra o armistício de Laques. Volvido um ano após a morte dos chefes das facções antagonistas em Anfípolis - Brásidas e Cléon - é celebrada a Paz de Nícias, em 421. Nesse mesmo ano expira o tratado de paz entre Argos e Esparta. Para que lado se passará Argos? A resposta é dada no Verão de 420 , com a celebração da aliança defensiva acima mencionada, em resposta à aliança firmada na Primavera do mesmo ano entre Esparta e os Beócios. Ainda que tenha os seus riscos procurar ecos de história próxima no teatro trágico (mesmo no de Eurípides), não deixa de ser evidente a coincidência entre a atmosfera do tempo e a da peça em questão. As palavras de Atena parecem conter um aviso a 
Argos - aviso que, a meu ver, reforça a mensagem de Os Heraclidas: a causa certa é a de Atenas. O eixo Esparta-Beócia é nefasto: Esparta é «insensível e pérfida», a Beócia, isto é, Tebas, representa o espaço da transgressão declarada, na peça. Eu veria como terminus ad quem 421-420 para a representação de As Suplicantes, num contexto histórico em que a sua mensagem trágica e a sua dimensão propagandística adquirem maior relevo.

De índole bem diversa é o discurso apologético de Atenas subjacente à trama dramática de íon. E a própria trama desta peça difere substancialmente da do grupo das restantes peças "atenienses" e de Medeia. As estratégias de construção dramática são também diferentes. Não há espaços distópicos, em contraste com o de Atenas, nem governantes idealizados que representem Atenas, por oposição à tirania de outros que representassem valores helénicos pervertidos. Em causa é posta a actuação de um deus, Apolo, por parte de uma Creúsa magoada como mulher. É que os planos do deus não são claros para os mortais e, por isso mesmo, chegam ao ponto de ver a sua realização falhada por má compreensão e sofrimento humanos. A Tyche parece ser a grande soberana dos acontecimentos - o que aproxima o clima desta peça do de peças posteriores de Eurípides e do da novela helenística e, até, da Comédia Nova ${ }^{25}$. Nestas vemos os característicos motivos do parente há muito perdido, julgado morto - para o caso, o parente típico «filho" -, a reaproximação aparentemente fortuita, sem reconhecimento, o falso conhecimento que chega a pôr em perigo vidas e a possibilidade de um encontro mais profundo e, por fim, o reconhecimento verdadeiro, através de sinais (as roupas com que a mãe o envolveu à nascença). No final tudo se ajusta e, no caso específico de ĺon, tudo se ajusta com a intervenção de Atena. Sobressaem, nesta tragédia, a frescura, inocência e dignidade do jovem Íon e a expressão de mágoa de Creúsa, que guarda consigo uma dor antiga e o peso de uma maternidade forçada por Apolo, silenciada e violentada, por ter tido de abandonar a criança que deu à luz e cujo destino desconhece - o que a faz duvidar da justiça e arbítrio divinos.

Em vez de criar a oposição entre espaços dramáticos idealizados e distópicos, Eurípides opta, aqui, por uma estratégica de entrelaçamento de espaços recorrendo intensivamente à ekphrasis, aliada ao motivo da autoctonia ateniense $A$ associação do espaço sagrado de um importante santuário à cidade de Atenas ocorre em As Suplicantes, entrecruzando-se, assim, o espaço sagrado ático por excelência à polis ateniense (também, a seu modo, espaço sagrado). Em ĺon a imbricação de espaços é bem mais ousada: a acção decorre no santuário de Delfos, o espaço sagrado 
pan-helénico por excelência, a que afluem consulentes de toda a Hélade. A consulta política e dinástica que a descendente dos Erectidas e seu marido, Xuto se preparam para fazer enquadra-se num padrão possível, de que outros mitos, como o da casa da Laio, fazem eco.

A identidade do Coro, constituído por servas de Creúsa, que acompanham a sua senhora, dá azo a que estas mulheres contemplem, extasiadas, os acessos ao templo e a ornamentação figurativa das métopas do próprio templo, à medida que se aproximam. Este canto de ekphrasis permite presentificar aos espectadores, no teatro ateniense, Delfos. No entanto, a comparação feita com a ornamentação dos templos atenienses, com a qual se inicia o párodo (vv. 184 sqq.), assim como o reconhecimento de motivos que são familiares ao Coro, ou de deuses tutelares da sua cidade, como Palas Atena ostentando o seu escudo (vv. 209-211), transportam, por sua vez, para Delfos a presença de Atenas ${ }^{26}$. No estásimo I o Coro invoca, no espaço délfico, a par dos deuses gémeos, filhos de Zeus, Apolo e Ártemis, a meia-irmã, filha de Zeus, "a nossa Atena", que aí tinha também representação (vv. 453-454).

Já, de resto, o monólogo inicial de Hermes obtivera esse efeito, ao evocar os antecedentes da história de Creúsa e Apolo.

De um outro modo, não empolgado mas dolorido, a visão do templo de Apolo desperta em Creúsa, no episódio I, a lembrança da violência erótica de que outrora foi vítima, por parte do deus, em Atenas ${ }^{27}$. O jovem Íon, por seu turno, ao saber que está diante da filha de Erecteu (assim se apresenta ela, v. 260), sem saber que se trata de sua mãe, aviva ainda mais essa dor da recordação ao pedir, insistentemente, a Creúsa que Ihe fale dos lugares de culto a Apolo em solo ateniense, mencionando as Rochas Altas, em cuja proximidade Erecteu foi engolido pelo solo. $\mathrm{O}$ lugar assinala também, sem que Íon o saiba, a união de Apolo a Creúsa e o seu próprio nascimento.

O espectador é, assim, levado a conferir uma particular atenção aos elos de autoctonia de Íon com Atenas ${ }^{28}$. Já Hermes, no prólogo, se havia referido aos Atenienses como "povo autóctone" (vv. 29-30)-motivo que, de resto, o jovem mas prudente lon retoma perante Xuto para pôr reservas à sua legitimidade como futuro governante de Atenas (vv. 589-590) - a "cidade pura" (v. 673), a "gloriosa Atenas", como várias vezes é referida (e.g. v. 1038) - supondo ser filho de um estrangeiro.

A tenda erguida por Íon para receber Xuto, o seu suposto pai, e os convivas, no banquete festivo, representa o momento alto dessa ekphrasis em que a associação de motivos tem como objectivo sugerir a associação de espaços e criar uma linguagem simbólica. A tenda, 
montada com tapeçarias pertencentes ao tesouro de ofertas votivas feitas a Apolo, parece representar o próprio universo da Hélade. É coberta por uma tela que representa o universo astral e que, indirectamente, assinala a presença e a acção de um herói pan-helénico - Héracles, a quem coube em sorte esta tela, proveniente do espólio da guerra com as Amazonas. As paredes são constituídas por "outras telas, bárbaras" (v. 1159), que representam os limites da Hélade: o monstruoso, o confronto naval entre Bárbaros e Helenos, motivos de caça, não apenas ao veado, mas caça ao leão feroz - realidade que nos aparece representada em espadas micénicas, de que os símiles épicos fazem eco, mas que não pertence ao universo da Grécia Clássica, antes ao do Próximo Oriente. A ornamentação da entrada é constituída por uma oferenda votiva feita por um Ateniense e evoca a autoctonia do ancestral monarca ateniense, Cécrops. As taças de ouro que ocupam o centro do espaço assinalam o centro desse universo, onde o banquete votivo terá lugar - como se constituíssem uma espécie de Delfos dentro de Delfos.

Eurípides constrói a descrição da cena, que põe na boca do Servo (vv. 1128-1167), de modo a sublinhar a confirmação da autoctonia ateniense, ainda que por um processo próximo do da ironia trágica: Íon presta-lhe vénia, ao escolher a tela de entrada da tenda. Todavia, pensando ser apenas filho de Xuto, sente-se como o estrangeiro que admira Atenas, filho de alguém que está ligado, por casamento, à casa real autóctone, mas filho, ainda assim, de um pai estrangeiro (epaktou, v.592) e nascido fora do casamento - um bastardo (nothogenes), "que não é ninguém, filho de ninguém" (vv. 592-594) ${ }^{29}$.

Como podem, então, realizar-se os sonhos sucessórios de seu pai, ainda que este seja alguém que foi útil a Atenas, mas que não é ateniense? Além das questões jurídicas levantadas, tais sonhos põem em risco a relação de autoctonia entre a terra e quem a governa. Nunca Creúsa o permitirá. Atesta-o a sua tentativa falhada de envenenamento do jovem e atestam-no as suas palavras ao jovem, que ainda não sabe ser seu filho, em 1296 ( «e como poderia o solo de Palas pertencer aos descendentes de Éolo?!» e 1299 («um estrangeiro aliado não pode possuir esta terra»).

O oráculo, na sua ambiguidade, separa momentaneamente os dois esposos chegados a Delfos com uma preocupação comum. Quanto a Xuto, pensando encontrar em ĺon um filho bastardo cuja existência não conhecia, vê a sua descendência perpetuada e deixa Creúsa só, com a sua amargura, sem perceber que essa descendência não pode governar Atenas.

Todavia, aquele que se identifica como potencial sucessor nãoautóctone - e que, por isso, viu a sua vida correr perigo - revelar-se-á, 
por acção da Pitonisa, que lhe mostra os sinais do seu nascimento, filho da autoctonia de Creúsa que, por sua vez, Ihe revelará a sua ascendência divina, como filho de Apolo. É, então, Creúsa quem esquece a amargura das recordações que a acompanham e se revê no filho recuperado.

Por interferência da Tyche os deuses têm dificuldade em tornar claros os seus planos, e correm, até, o risco de assumirem uma dimensão de crueldade e injustiça aos olhos dos mortais, enredados numa trama que não compreendem e de que se sentem vítimas. Creúsa, magoada com o seu passado e revoltada com o futuro que se antevê para uma Atenas governada por um estrangeiro, reage. É a sua violenta reacção, de mulher e de Ateniense, que, de certo modo, acelera a revelação da identidade de ĺon e dos planos do deus, como se este se encontrasse, finalmente, espaço para se redimissir, quando a trama parece, também atingi-lo.

Tal como no entrelaçar de espaços através do discurso ecfrástico, através da revelação da identidade de ĺon Atenas e Delfos associam-se. Mais ainda: a intervenção final de Atena ex machina, epónima da Cidade, como declara (v.1555), coincidente com o bem da Cidade, que protege na Ática ou em outro lugar, como também afirma (vv. 1553-1554), desperta no espectador a consciência de que, pela sua deusa protectora, Delfos e Atenas se associam inextricavelmente e de que o papel de Delfos é, assim, clarificado.

Para além do nível do discurso que diz respeito à acção da peça, um outro nível ganha consistência: Atenas protegerá a presença ateniense para além da Ática, ainda que as circunstâncias pareçam adversas. A partir desta mensagem implícita é impossível extrair conclusões sobre a datação da peça: tanto pode aquela representar uma posição de confiança, em tempos mais propícios na guerra, como pode representar um apelo ao ânimo em tempos menos propícios.

A genealogia prevista por Atena dos lónios a partir da descendência de Íon representa, certamente, um apelo à aliança entre Atenienses e lónios, baseado nos laços de origem e nos traços comuns que os aproximam. Tal apelo põe, como o nota Lesky ${ }^{30}$, o ano de 412 a. C. como terminus ad quem, ano da queda da Liga lónia. A referência a Ríon (v. 1592), na Acaia, poderá conter uma alusão próxima à incursão de Alcibíades no Peloponeso, no Verão de 419, persuadindo os habitantes de Patras a fortificarem o seu corredor de acesso ao mar e tentando, ele mesmo, construir uma fortaleza uma fortaleza no promontório de Ríon (iniciativa impedida pelos habitantes de Corinto e de Sícion, de acordo com Tucídides, 5. 52). Pode, no entanto, ser apenas mera reminiscência, referida posteriormente. 
Esta tragédia, mais que qualquer outra, mostra, bem explicitamente, uma dimensão de propaganda ateniense que, simultaneamente, põe em causa ancestrais convicções de uma Atenas que o poeta parece acreditar estar ultrapassada.

A convicção da autoctonia fundamenta os critérios estreitos de cidadania, porque se crê que a pólis nasce da natureza, mais do que de leis, feitas por deuses ou por homens (por aqueles inspirados). O estatismo da autoctonia é coincidente com a convicção de que sempre a physis, nunca a paideia ou o nomos, deverão determinar, invariavelmente, a vida e o futuro da pólis - uma pólis fechada. Como refere A. Saxonhouse (1986, p. 259) ${ }^{31}$, a autoctonia ignora o papel da mulher na pólis, no oikos, já que a semente primordial gera a partir da terra, sem gestação no ventre feminino. A mulher será, a partir daí, vista como mera terra arável pelo homem. Mas, mais ainda, a autoctonia, no seu estatismo, é avessa a ideais de uma sociedade democrática aberta e sanciona uma aristocracia autocrática, ligada à terra, uma comunidade xenófoba ${ }^{32}$.

Eurípides concilia, então, a antiga tradição da autoctonia com a necessária abertura de Atenas, patente na parrésia que cultiva e que é seu apanágio, à sua vocação de pólis representante do espírito helénico, germe de um pan-helenismo ideal, através do entrelaçar de Atenas e Delfos no canto das belezas de ambas e no próprio mythos trágico. A descendência feminina dos nascidos da terra ática só pode conceber um descendente que não seja filho de um cidadão se a paternidade deste for inquestionável, para além do estatuto do polites, ainda assim mortal. A paternidade divina, olímpica, resguarda a autoctonia e resgata-a, por essa sua dimensão olímpica, para um plano mais elevado, de onde as perspectivas são mais largas. O espaço de Delfos, na altura das montanhas, em que Íon foi criado, insinua-o.

Por outro lado, Apolo tem, necessariamente, de dar sentido e amplitude ao oikos de Creúsa e Xuto. Os filhos mortais que ambos gerarão não serão atenienses, mas pan-helénicos. Sedimentarão laços de pertença e afinidade entre os Gregos, tal como Atena, cujo âmbito de acção e protecção extravasa Atenas, protegendo o que a Atenas está ligado, mas também ao que aos deuses seus irmãos diz respeito.

O poeta está já para além da apresentação de personagens-modelo, de oposições de espaços políticos. Estes podem reportar-se ainda a uma fase de guerra civil em que o espírito partidário se alimenta da convicção da causa justa, do lado justo. ĺon, em meu entender, enquadra-se numa outra fase, posterior, de desencanto com "causas justas" e "facções certas". Representa uma nova dimensão publicitária no seu apelo ao que Atenas 
pode representar, a partir das suas origens e das suas relações primordiais com a Hélade, para além de uma guerra que, como todas as guerras, é injusta, sangrenta, cruel. É bem possível que Hécuba e Troianas tivessem já sido compostas e representadas. O que une os homens continua, em parte a ser a sua ligação à terra, como entidade verdadeiramente estável, perante os enganos provocados pelo denominador comum que é o efeito da Tyche sobre o destino humano, causadora da separação entre os homens e, porventura, da agnoia sobre a identidade de cada homem e sobre o que isso acarreta de sofrimento. Sendo Creúsa descendente de autóctones, a marca de ascendência da terra permanecerá, mais ténue, em todos os seus descendentes, filhos da sua ligação a Xuto. Mais forte será essa ligação nos descendentes de ĺon.

Dou razão aos que, como Solmsen ${ }^{33}$ e, na sua esteira, Lesky ${ }^{34}$ consideram a peça mais próxima de Helena, Electra ou Ifigénia entre os Tauros, destacada do conjunto das outras "peças atenienses». Nesse conjunto, como penso haver demonstrado, deve Medeia ser incluída. E tal inclusão deita, sobre esta tragédia apresentada por Eurípides nas Gandes Dionísias da primavera de 431 a. C., uma nova luz enriquecedora da sua compreensão ${ }^{35}$.

\section{Notas}

(1) Essa consciência, que começa a tomar relevo a partir da década de sessenta, encontra no precioso livro de Meier, 1988, um dos seus momentos mais decisivos.

(2) Saxonhouse, 1986, 273 manifesta a sua discordância em relação à compreensão desta peça como sendo de propaganda política ateniense: "Some have read Ion as a propaganda piece written for Athenians eager to defend their citizenship laws by reference to their divine origins. However, to read the Play in this way is to ignore the critique implicit in it and to obscure the subtle interplay between male and female that undermines the Athenians' self-satisfaction in their masculine policy".

(3) Fialho 2006, 58-63; Fialho 2006, 2, 23sqq; Silva 2005, 221 sqq.

(4) Fialho 2006, 63.

(5) Dunkle, 1969, 98-100. Contra esta perspectiva, Rocha Pereira, 2005, 26-27.

(6) Veja-se a pelike das Antikensammlungen de Munique, na qual se pode observar a ascensão de Héracles ao Olimpo. Cf. Burkert 1977, 319-324.

(7) Halleran 1985, 82 afirma com toda a pertinência: “Theseus' friendship, however, proving itself in the testo of difficulties, offers some solace and strength. The conquerer of so many beasts has himself been brought low, but with Theseus' friendship, he has at least survived".

(8) Veja-se a excelente obra de Walker, 1995. Este autor sintetiza, em pp. 127 sqq., o papel de Teseu na peça: "The play cannot end with a deus ex machina. This role is played instead by a mortal, Theseus, and the social bond between human beings replaces the claims of nobility 
to divine origins. The "yoje" of firendship between two mortals... is modeled on the horizontal relationship of marriage ... like marriage, friendship is social rather than natural, and it is an union that is chosen deliberately. It surpasses in importance the vertical line of descent..."

(9) Barlow 1982, 124 observa, acerca da coerência estrutural de Héracles: "The play is thus rich in contrasting levels of dramatic reality, as indeed many of Euripides' other plays are, and this is effected through certain juxtaposed structural high points... This is a non-logical, non-Aristotelian arrangement of sequence but one can hardly call it "mere juxtaposition" but calculated juxtaposition as a dramatic method itself».

(10) Grégoire-Parmentier 1994, 15-16.

(11) López Férez 1988, 367. Cf. Lesky 1972, 375

(12) Lesky 1995, 409.

(13) Magdeleine 2003, 108 sqq.

(14) Sobre esta matéria veja-se a excelente síntese de posições elaborada por Cravo da Silva, $2000,15-23$.

(15) 12. 45 .

(16) Ferreira, 1992, 176-181, fazendo uso das fontes antigas, enumera alguns dos princípios éticos de comportamento na guerra, em relação a vencidos. Para além do princípio em causa refere, também, a obrigação de restituir os cadáveres dos vencidos para que lhes sejam prestadas honras funerárias. Trata-se de assegurar princípios que, para os Gregos, constituem o fundamento da civilização e da ordem social: vide Conacher, 1967, 97.

(17) Dou razão à argumentação de Cravo da Silva que reconhece maior consistência à tradição atestada em Estrabão, 8. 6. 9, que dá Euristeu sepultado em Gargeto, demo ático próximo do de Palene.

(18) Wilkins, 1990, 337-339.

(19) Zuntz, 1955, 26-54; Cravo da Silva, 2000, 93-94.

(20) Para Fitton, 1961, 431, o ponto de viragem da tragédia assenta na persuasão de Teseu por sua mãe.

(21) Walker, 1995, 143-169, propõe uma interessante leitura de evolução de Teseu em As Suplicantes, a que não é alheio o papel feminino de Etra: de sofista, a governante democrático, a representante de valores pan-helénicos e a herói vitorioso, regressado da guerra.

(22) Sobre a discussão à cerca deste possivel motivo veja-se Fitton, 1961, 436 e 442-443. Veja-se, também, Romilly, 1969, 178-179.

(23) Ferreira, 1985-1986, 103.

(24) Ferreira, ibid. 89.

(25) Cfr. Solmsen, 1968, 442 e 447-448, Mastronarde, 1975, 165, Quijada Sagredo, 2004, 380-381.

(26) Em relação a outros aspectos da simbologia figurativa, vide Mastronarde, 1969, 164 sqq.

(27) Nota Quijada Sagredo, 2011, 53, que quatro vezes é Apolo referido como Loxias, no relato de Hermes, como que insinuando o comportamento enviesado que o deus tem para com o destino, até ali, de seu filho.

(28) Sobre a importância dramática da afinidade de circunstâncias entre o autóctone Erictónio e Ílon, concebido, nascido e exposto na gruta, guardado por serpentes, vide Lourenço, 1994, 25-26. 
(29) Vide Vidal-Naquet, 1997, 116.

(30) Lesky, 1972, 425-426.

(31) $1986,259$.

(32) Saxonhouse, 1986, 255 sqq. Sobre a ligação à terra como pertença congénita, vide Leão, 2010.

(33) $1968,429$.

(34) Lesky, 1972, 426.

${ }^{(35)}$ Este artigo corresponde a uma análise mais amplificada de M. C. Fialho, «Propaganda ateniese nel teatro di Euripide” in F. De Martino (ed.), Antichità \& Pubblicità, Bari, Levante, 2010, 233-260.

\section{Bibliografia:}

Sh. A. BARLOW, "Structure and Dramatic Realism in Euripides'Heracles", G\&R29/2, 1982, 115-125. W. BURKERT, Griechische Religion, Stuttgart, 1977.

D. J. CONACHER, Euripidean Drama. Myth, Theme and Structure, Toronto, 1967.

C. R. Cravo da SILVA, Euripides. Os Heraclidas, introd. trad. do grego, notas, Lisboa, 2000.

J. R. DUNKLE, "The Aegeus Episode and the Theme of Euripides' Medea", TAPhA 100, 1969, 97-107.

J. R. FERREIRA, Hélade e Helenos. Génese e evolução de um conceito, Coimbra, 1992.

J. R. FERREIRA, “Aspectos políticos nas Suplicantes de Eurípides», Humanitas, 1985-1986, 87-121.

M. C. FIALHO, «A Medeia de Eurípides e o espaço trágico de Corinto» in E. Suárez de la Torre, M. C. Fialho (eds.), Bajo el signo de Medea/Sob o signo de Medeia, Coimbra/Valadolid, 2006, 13-19.

M. C. FIALHO, "O motivo da philia na Medeia de Eurípides" in Actas do Colóquio de Estudos Clássicos "A Antiguidade Clássica e nós: Herança e identidade cultural», Braga, 2006, 53-64.

M. C. FIALHO, «Propaganda ateniese nel teatro di Euripide» in F. De Martino (ed.), Antichità \& Pubblicità, Bari, Levante, 2010, 233-260.

J. W. FITTON, «The Suppliant Women and the Herakleidai of Euripides", Hermes 89/4, 1961, 431-461.

M. HALLERAN, Stagecraft in Euripides, London \& Sydney, 1985.

D. LEÃO, "Cidadania, autoctonia e posse da terra na Atenas democrática", Cadmo 20, 445-464.

A. LESKY, História da Literatura Grega, Lisboa, 1995 (trad. do al., 1971³).

A. LESKY, Die tragische Dichtung der Hellenen, Göttingen, $1972^{3}$.

J. A. LÓPEZ FÉREZ, “Eurípides» in J. A. López Férez (ed.), Historia de la Literatura Griega, Madrid, $1988^{2}, 352-405$.

F. LOURENÇO, Eurípides. Ín, trad., do grego, introd., notas, Lisboa, 1994. 
C. MAGDELEINE, "Le vocabulaire du peuple et de la démocartie chez Euripide», Ktema 28, 2003, 105-121.

D. MASTRONARDE, “Iconography and Imagery in Euripides' Ion", Cl. Ant. 8, 1975, 163-176.

Ch. MEIER, Die politische Kunst der Tragödie, München, 1988.

M. QUIJADA SAGREDO, "El elaborado narrativo del lón de Eurípides: final de una época?» in J. M. Nieto Ibañez (ed.), Logos Hellenikos. Homenaje al Professor Gaspar Morocho Gayo, León, 2004.

M. QUIJADA SAGREDO, "El Eurípides tardio y los limites de la tragédia» in M. Quijada Sagredo (ed.), Estudios sobre Tragédia Griega. Eurípides, el teatro griego de finales del siglo $\mathrm{V}$ a. C. y su influencia posterior, Madrid, Ed. Clásicas, 2011, 31-48.

J. de ROMILLY, “ll pensiero di Euripide sulla tirania», Dioniso 43, 1969, 175-187.

M. H. Rocha PEREIRA, Eurípides. Medeia, introd. versão do grego e notas, Lisboa, $2005^{3}$.

A. W. SAXONHOUSE, "Myths and the Origins of Cities: Reflections on the Autochthony Theme in Euripides' Ion" in J. P. Euben (ed.), Greek Tragedy and Political Theory, Berkeley-Los Angeles-London, 1986, 252-273.

M. F. SILVA, «Representações de alteridade no teatro de Euripides: o Bárbaro e o seu mundo" in M. C. Fialho, M. F. S. Silva, M. H. Rocha Pereira (eds.), Génese e consolidação da ideia de Europa, Coimbra, 2005, 187-237.

F. SOLMSEN, "Euripides lon im Vergleich mit anderen tragödien» in E. Schwinge (ed.) Euripides, Darmstadt, 1968, 428-468.

P. VIDAL-NAQUET, "The Place and Status of Foreigners in Athenian Tragedy" in Ch. Pelling (ed.), Greek Tragedy and the Historian, Oxford, 1997, 109-119.

H. J. WALKER, Theseus \& Athens, New York/Oxford, 1985.

J. WILKINS, "The Young Athens: Religion and Society in Heracleidai of Euripides", CQ 40/2, 1990, 329-339.

G. ZUNTZ, The Political Plays of Euripides, Manchester, 1955. 